\title{
HOSPITALIZED SENILE CATARACT IN DIFFERENT JEWISH COMMUNITIES IN ISRAEL*
}

BY

\author{
H. S. HALEVI AND J. LANDAU \\ Ministry of Health and Hadassah Hebrew University Hospital, Jerusalem, Israel
}

A PREVIOUS paper reported the incidence of glaucoma in the Jewish population of Israel (Landau and Halevi, 1960). The cases of senile cataract admitted to the same ophthalmological departments during the two years 1956-1957 have been analysed in the same way.

\section{Material and Methods}

Altogether 1,130 cases of cataract were registered in patients aged 40 years and over, including 640 of European origin and 490 orientals from the Middle East and North Africa (Yemen, Iraq, Iran, Morocco, Tunisia, Libya, etc.) (Table I).

TABLE I

CASES OF CATARACT, BY SEX, AGE, AND COMMUNITY OF ORIGIN

\begin{tabular}{|c|c|c|c|c|c|c|c|c|}
\hline \multirow{2}{*}{\multicolumn{2}{|c|}{$\begin{array}{l}\text { Sex } \\
\text { Origin }\end{array}$}} & \multicolumn{2}{|c|}{ Male } & \multicolumn{2}{|c|}{ Female } & \multicolumn{3}{|c|}{ Total } \\
\hline & & European & Oriental & European & Oriental & European & Oriental & All Cases \\
\hline$\underset{\text { (yrs) }}{\text { Age }}$ & \begin{tabular}{|c}
$49-49$ \\
$50-59$ \\
$60-69$ \\
$70+$ \\
Not \\
known
\end{tabular} & $\begin{array}{r}24 \\
59 \\
101 \\
106 \\
-\end{array}$ & $\begin{array}{l}22 \\
71 \\
77 \\
81 \\
-\end{array}$ & $\begin{array}{r}22 \\
61 \\
132 \\
134 \\
1\end{array}$ & $\begin{array}{r}29 \\
68 \\
73 \\
68 \\
1\end{array}$ & $\begin{array}{r}46 \\
120 \\
233 \\
240 \\
1\end{array}$ & $\begin{array}{r}51 \\
139 \\
150 \\
149 \\
1\end{array}$ & $\begin{array}{r}97 \\
259 \\
383 \\
389 \\
2\end{array}$ \\
\hline Total & & 290 & 251 & 350 & 239 & 640 & 490 & 1,130 \\
\hline
\end{tabular}

All other cases of cataract (traumatic, due to metabolic disturbances, complicated, and others) were excluded. No distinction was made between nuclear and cortical cataracts. Operations were performed on all these cases. These figures were related to the numbers of the respective population groups and incidence rates were calculated by the method of Landau and Halevi (1960).

\section{Results}

The rates of incidence of cataract in the population are given in Table II (overleaf).

These rates increase with age, and reach a high incidence after age 60 . There are no great differences between males and females in either community. Taken together, the rate for males is $10 \cdot 26$ per 10,000 as against $11 \cdot 27$ 
TABLE II

INCIDENCE OF CATARACT PER 10,000 PERSONS, BY AGE, SEX, AND COMMUNITY OF ORIGIN

\begin{tabular}{|c|c|c|c|c|c|}
\hline \multirow{2}{*}{\multicolumn{2}{|c|}{$\frac{\text { Sex }}{\text { Origin }}$}} & \multicolumn{2}{|c|}{ Male } & \multicolumn{2}{|c|}{ Female } \\
\hline & & European & Oriental. & European & Oriental \\
\hline$\underset{\text { (yrs) }}{\text { Age Group }}$ & $\begin{array}{l}40-49 \\
50-59 \\
60-69 \\
70+\end{array}$ & $\begin{array}{r}1 \cdot 42 \\
4.50 \\
16.68 \\
40 \cdot 36\end{array}$ & $\begin{array}{r}3 \cdot 76 \\
15 \cdot 75 \\
32 \cdot 73 \\
63 \cdot 30\end{array}$ & $\begin{array}{r}1 \cdot 30 \\
5.49 \\
21.93 \\
38 \cdot 33\end{array}$ & $\begin{array}{r}4.54 \\
15.09 \\
29.57 \\
50.31\end{array}$ \\
\hline
\end{tabular}

for females, a difference which is not statistically significant (S.E. $\pm 0 \cdot 91$; D. 1.01). But a comparison of parallel age and sex groups in the two communities shows evident differences with a considerable preponderance of orientals.

A calculation of the standard error of the differences between the two communities at various ages shows that most of them are significant at the 5 per cent. level (Table III).

TABLE III

SIGNIFICANCE TEST OF DIFF ERENCE BETWEEN COMMUNITIES, BY AGE AND SEX

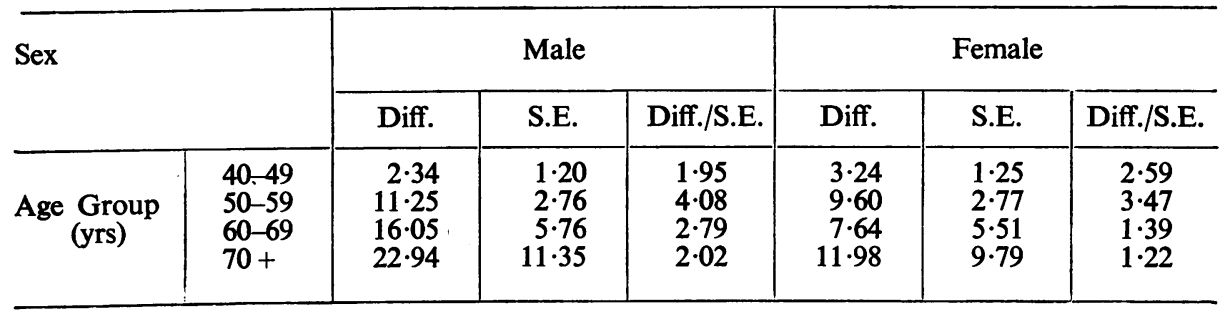

Only the two eldest groups of women show no significant difference. The significance is not parallel for both sexes. In the $\mathbf{4 0}$ to 49 -year-old group, the difference for men is hardly significant, while it is highly so for women. In the older groups the opposite situation prevails: in the 60 to 69 -year-old group, the difference for men is highly significant, but for women it is not significant.

\section{Discussion}

There are not many reports which analyse the frequency of cataract in different ethnic groups, although statistical evidence of cataract in various countries is available. Duke-Elder (1940) presents two estimates of changes in the lens at different ages as found in a screening of population samples in Scandinavia (by Andersen, 1925) and in the U.S.A. (by Gradle, 1926). The frequency of these changes was found to be over one-third in the 41 to 50 year-old group, and increased gradually to over 90 per cent. in the $70+$ age 
group. No great differences can be recognized between the two regions. These figures include all stages of senile cataract from the beginning of development, but the present study includes only mature or nearly mature cases that were admitted to the hospitals for operation. Fuchs (1960) quotes figures observed in different parts of the world at different periods. They all represent proportions of cataract cases of all eye-patients admitted to hospital. There is wide variation in the percentages and Fuchs draws no definite conclusions regarding differential frequency. Although he deals at length with the situation in India, he cites conflicting opinions and leaves the problem open. Our observations are based on the total population of Israel and not on eye-patients only and it is therefore advisable to record any comparisons here.

We have tried to obtain figures for comparison from two geographically opposite countries: Sweden in Northern Europe and Thailand in South-East Asia. Unfortunately the material received was very different in its composition and the method of comparison with the material from Israel varies accordingly.

From Sweden we received in a private communication the distribution of the general population by age on January 1, 1959, and the total number of cataract operations performed during 1958 . In a population of $7,436,066$ persons, 3,510 operations took place, a crude rate of $4 \cdot 7$ per 10,000 . If only persons aged over 40 are included, the rate of cataract operations rises to 10.8 per 10,000 , but even then it may be influenced by the different composition of the populations of Sweden and Israel (Table IV).

TABLE IV

PERCENTAGES OF POPULATION AGED 40 AND OVER IN SWEDEN AND ISRAEL

\begin{tabular}{|c|c|c|c|c|c|}
\hline \multirow{2}{*}{\multicolumn{2}{|c|}{ Country }} & \multirow{3}{*}{$\begin{array}{c}\text { Sweden } \\
32 \cdot 8 \\
29 \cdot 2 \\
21 \cdot 2 \\
16 \cdot 7\end{array}$} & \multicolumn{3}{|c|}{ Israel } \\
\hline & & & \multirow{2}{*}{$\begin{array}{c}\text { European } \\
44 \cdot 7 \\
31 \cdot 8 \\
15 \cdot 3 \\
8.0\end{array}$} & \multirow{2}{*}{$\begin{array}{c}\text { Oriental } \\
42 \cdot 7 \\
31 \cdot 4 \\
16 \cdot 8 \\
9 \cdot 1\end{array}$} & \multirow{2}{*}{$\begin{array}{r}\text { Total } \\
43 \cdot 9 \\
31 \cdot 7 \\
16 \cdot 1 \\
8 \cdot 3\end{array}$} \\
\hline $\begin{array}{l}\text { Age Group } \\
\text { (yrs) }\end{array}$ & $\begin{array}{l}40-49 \\
50-59 \\
60-69 \\
70+\end{array}$ & & & & \\
\hline \multicolumn{2}{|c|}{ Total } & 100 & 100 & 100 & 100 \\
\hline \multicolumn{2}{|c|}{$\begin{array}{c}\text { Percentage Aged } \\
40+\text { in Total Population }\end{array}$} & $43 \cdot 7$ & $38 \cdot 6$ & $18 \cdot 6$ & $28 \cdot 6$ \\
\hline
\end{tabular}

To eliminate this difference we tried to standardize the rates for Israel (Europeans and orientals) on the age distribution in Sweden. In this way we calculated the number of cataract cases which might be expected in Sweden by Israeli rates (Table V, overleaf). 
TABLE V

EXPECTED CASES OF CATARACT IN SWEDEN, BY ISRAELI AGE-SPECIFIC RATES

\begin{tabular}{|c|c|c|c|c|c|}
\hline \multirow{2}{*}{\multicolumn{2}{|c|}{ Israeli Population }} & \multicolumn{2}{|c|}{ European } & \multicolumn{2}{|c|}{ Oriental } \\
\hline & & \multirow{2}{*}{$\begin{array}{c}\begin{array}{c}\text { Rate per } \\
10,000\end{array} \\
1 \cdot 36 \\
4 \cdot 95 \\
19 \cdot 30 \\
39 \cdot 20 \\
8 \cdot 39\end{array}$} & \multirow{2}{*}{$\begin{array}{c}\begin{array}{c}\text { Expected Cases } \\
\text { in Sweden }\end{array} \\
145 \cdot 1 \\
470 \cdot 1 \\
1,332 \cdot 2 \\
2,124 \cdot 4 \\
4,071 \cdot 8\end{array}$} & \multirow{2}{*}{$\begin{array}{c}\begin{array}{c}\text { Rate per } \\
10,000\end{array} \\
4 \cdot 16 \\
15 \cdot 42 \\
31 \cdot 11 \\
56 \cdot 72 \\
17 \cdot 06\end{array}$} & \multirow{2}{*}{$\begin{array}{c}\begin{array}{c}\text { Expected Cases } \\
\text { in Sweden }\end{array} \\
444 \cdot 0 \\
1,464 \cdot 6 \\
2,147 \cdot 4 \\
3,073 \cdot 8 \\
7,129 \cdot 8\end{array}$} \\
\hline $\begin{array}{l}\text { Age Group } \\
\text { (yrs) }\end{array}$ & $\begin{array}{l}40-49 \\
50-59 \\
60-69 \\
70+ \\
40 \text { and over }\end{array}$ & & & & \\
\hline \multicolumn{2}{|c|}{$\begin{array}{l}\text { Expected Rate of Incidence } \\
\text { of Cataract in Sweden }\end{array}$} & - & $12 \cdot 5$ & - & $21 \cdot 9$ \\
\hline
\end{tabular}

Actually Sweden had $10 \cdot 8$ cases of cataract per 10,000 inhabitants aged 40 years and over; if the rates for Europeans in Israel prevailed in Sweden, the rate would rise to $12 \cdot 5$, but according to the rates for orientals in Israel it would rise to 21.9 . Both these differences are highly significant $(p<0.01)$. This means that the rates for both parts of the population in Israel, and particularly for the orientals, are higher than in Sweden. For the European Jews, coming mainly from Eastern and Central Europe, the difference is moderate $(12 \cdot 5-10 \cdot 8)$, whereas for the oriental Jews, coming mainly from the Middle East and North Africa, the difference is very large (21.9-10.8).

For Thailand we obtained the numbers of cataract cases admitted to two leading hospitals in Bangkok during the years 1957-59, a total of 1,713 cases. These included 1,328 Thai, 356 Chinese, and 29 Indian patients. Unfortunately, no information is available about the size of the whole population among whom these cases occurred, so that rates of frequency could not be calculated. Our analysis for Thailand is therefore limited to the breakdown of the hospitalized cases by age and sex in each community (Table VI).

TABLE VI

CATARACT CASES IN TWO HOSPITALS IN BANGKOK, BY COMMUNITY, AGE, AND SEX, 1957-59

\begin{tabular}{|c|c|c|c|c|c|c|c|}
\hline \multirow{2}{*}{\multicolumn{2}{|c|}{$\begin{array}{l}\text { Community } \\
\text { Sex }\end{array}$}} & \multicolumn{2}{|c|}{ Thai } & \multicolumn{2}{|c|}{ Chinese } & \multicolumn{2}{|c|}{ Indian } \\
\hline & & \multirow{2}{*}{$\begin{array}{c}\text { Male } \\
64 \\
147 \\
218 \\
146\end{array}$} & \multirow{2}{*}{$\begin{array}{c}\text { Female } \\
75 \\
184 \\
219 \\
151\end{array}$} & \multirow{2}{*}{$\begin{array}{c}\text { Male } \\
16 \\
50 \\
79 \\
43\end{array}$} & \multirow{2}{*}{$\begin{array}{c}\text { Female } \\
18 \\
46 \\
52 \\
28\end{array}$} & \multirow{2}{*}{$\begin{array}{c}\text { Male } \\
1 \\
7 \\
8 \\
4\end{array}$} & \multirow{2}{*}{$\begin{array}{c}\text { Female } \\
\frac{1}{5} \\
-\end{array}$} \\
\hline$\underset{\text { (yrs) }}{\text { Age }}$ & $\begin{array}{l}40-49 \\
50-59 \\
60-69 \\
70+\end{array}$ & & & & & & \\
\hline Total & & 575 & 629 & 188 & 144 & 20 & 6 \\
\hline
\end{tabular}


The decrease in the numbers of cataracts in the oldest age group may possibly be explained by the fact that, in a country where the expectation of life is 48.5 years for males and 51.4 for females (Ministry of Public Health, Bangkok, 1960), there is a marked fall in the total population in the higher age groups.

In our analysis we omitted the group of Indians because their numbers were so small. The breakdown of the Thai and Chinese patients by age and sex is compared with a similar breakdown of European and oriental patients in Israel (Table VII).

TABLE VII

BREAKDOWN OF CATARACT CASES, BY AGE AND SEX IN ISRAEL AND IN TWO HOSPITALS IN THAILAND

\begin{tabular}{|c|c|c|c|c|c|c|c|c|c|}
\hline \multirow{3}{*}{\multicolumn{2}{|c|}{$\begin{array}{l}\text { Country } \\
\text { Community } \\
\text { Sex }\end{array}$}} & \multicolumn{4}{|c|}{ Israel } & \multicolumn{4}{|c|}{ Thailand } \\
\hline & & \multicolumn{2}{|c|}{ European } & \multicolumn{2}{|c|}{ Oriental } & \multicolumn{2}{|c|}{ Thai } & \multicolumn{2}{|c|}{ Chinese } \\
\hline & & Male & Female & Male & Female & Male & Female & Male & Female \\
\hline$\underset{\substack{\text { Group } \\
\text { (yrs) }}}{\text { Age }}$ & $\begin{array}{l}40-49 \\
50-59 \\
60-69 \\
70+\end{array}$ & $\begin{array}{r}3 \cdot 8 \\
9 \cdot 2 \\
15 \cdot 8 \\
16 \cdot 6\end{array}$ & $\begin{array}{r}3.4 \\
9.5 \\
20.7 \\
21.0\end{array}$ & $\begin{array}{r}4 \cdot 5 \\
14.5 \\
15 \cdot 7 \\
16 \cdot 6\end{array}$ & $\begin{array}{r}5.9 \\
13.9 \\
14.9 \\
13.9\end{array}$ & $\begin{array}{r}5 \cdot 3 \\
12 \cdot 2 \\
18 \cdot 1 \\
12 \cdot 1\end{array}$ & $\begin{array}{r}6 \cdot 2 \\
15 \cdot 3 \\
18 \cdot 2 \\
12 \cdot 5\end{array}$ & $\begin{array}{r}4 \cdot 8 \\
15 \cdot 1 \\
23 \cdot 8 \\
13 \cdot 0\end{array}$ & $\begin{array}{r}5.4 \\
13.9 \\
15 \cdot 7 \\
8.4\end{array}$ \\
\hline \multicolumn{2}{|l|}{ Total } & $45 \cdot 3$ & $54 \cdot 6$ & $51 \cdot 3$ & $48 \cdot 7$ & $47 \cdot 8$ & $52 \cdot 2$ & $56 \cdot 6$ & $43 \cdot 3$ \\
\hline \multicolumn{2}{|c|}{ Grand Total } & \multicolumn{2}{|c|}{100} & \multicolumn{2}{|c|}{100} & \multicolumn{2}{|c|}{100} & \multicolumn{2}{|c|}{100} \\
\hline \multicolumn{2}{|c|}{ No. of Cases } & \multicolumn{2}{|c|}{639} & \multicolumn{2}{|c|}{489} & \multicolumn{2}{|c|}{1,204} & \multicolumn{2}{|c|}{332} \\
\hline
\end{tabular}

The significance of the difference between these various groups was tested by the $\chi^{2}$ test, with the following results:

\begin{tabular}{l|l|l}
\hline \multicolumn{2}{l|}{ Thai and Chinese } & Not significant \\
\hline Europeans (Israel) & $\begin{array}{l}\text { and Thai } \\
\text { and Chinese }\end{array}$ & Highly significant \\
\hline Orientals (Israel) & $\begin{array}{l}\text { and Thai } \\
\text { and Chinese }\end{array}$ & Not significant \\
\hline
\end{tabular}

There is a similarity between the oriental Jews in Israel and both ethnic groups in Thailand. But there is a dissimilarity between the European Jews in Israel and the patients in Thailand.

Although the comparisons with Sweden and Thailand were made by different methods, it seems that one general conclusion can be drawn: there is apparently a geographical distribution of the cataract, the lowest incidence 
being found in Sweden in the North and the highest in Thailand in the South. Israel has groups originating in Europe that are near the Swedish pattern and groups originating in the Middle East that are near to the Asian pattern. This also accords with the general opinion about the high prevalence of cataract in India (Fuchs, 1960).

\section{Summary}

(1) For the years 1956-57, 1,128 cases of senile cataract in Israel have been analysed by community of origin, age, and sex.

(2) The incidence among oriental Jews is significantly higher than among European Jews.

(3) No significant sex difference was found.

(4) The incidence in each community increases with age, as might be expected.

(5) A comparison of the Israeli statistics with figures from Sweden and Thailand points to the possibility of a geographic distribution of the cataract.

We wish to express our sincere thanks and appreciation to Miss M. Hagberg, of the Swedish Institute, Stockholm, and the Swedish Committee on International Health Relations, and to Dr. B. Subhamani, Ministry of Health, Thailand, for their trouble in supplying us with the figures from their countries.

Our thanks are also due to the Records Officers of the Government Hospitals, Tel Hashomer, Rambam, and Jaffa, and the Hadassah University Hospital, Jerusalem, for collecting the necessary data.

\section{REFERENCES}

ANDERSEN, C. L. (1925). Acia ophthal. (Kbh.), 2, 250.

Duke-ElDER, S. (1940). "Text-book of Ophthalmology", vol. 3, p. 3193. Kimpton, London. FucHs, A. (1960). Amer. J. Ophthal., 49, 1039.

Gradle, H. S. (1926). In "Contributions to Ophthalmic Science: dedicated to Dr. Edward Jackson", ed. W. H. Crisp and W. C. Finnoff. George Banta Publ. Co., Menasha, Wisconsin.

LANDAU, J., and Halevi, H. S. (1960). Brit. J. Ophthal., 44, 751.

Ministry OF Public Health (Thailand) (1960). "Public Health in Thailand", p. 3. Bangkok. 